INTERNATIONAL JOURNAL OF RESEARCHES IN BIOSCIENCES, AGRICULTURE \& TECHNOLOGY (C) VISHWASHANTI MULTIPURPOSE SOCIETY (Global Peace Multipurpose Society) R. No. MH-659/13(N) www.vmsindia.org

\title{
PRANAYAMA AND MEDITATION BRINGS GOOD CONTROL IN TYPE 2 DIABETIES MELLITUS
}

\author{
${ }^{1}$ Rohankar P.H., ${ }^{1}$ Kale S. A and ${ }^{2}$ Kalbande A.G. \\ ${ }^{1}$ Govt. Vidharbha Institute of Sciences and Humanities, Amravati (M.S) India \\ ${ }^{2} \mathrm{PDMC}$, Amravati (M.S) India \\ Email: rohankarp@yahoo.com
}

\begin{abstract}
The aim of this study is to find out the impact of Pranayam and Meditation on fasting Blood glucose among the Type 2 Diabetic Patients. One twenty days study intervention was conducted using a single center of serial Diabetic camps conducted by Dialectological Association, Amravati Branch of India. The blood samples were collected from T2DM Patients and tested for Blood glucose, by GOD-POD (Glucose Oxidase -peroxidase) method. After initial testing for Blood glucose, Patients was instructed to do all types of pranayam and meditation as per table No. I for 120 days. That patients were again tested for Blood glucose. (pranayam and Meditation) blood glucose results were poaked separately and statistically analyzed by paired " $t$ " test .Equal numbers of healthy controls was included in the study. Pranayama and mediation shown to have significant impact on blood glucose in T2DM patients.
\end{abstract}

Keywords: Pranayam, Meditation, Diabetes, Type 2 Diabetes Mellitus

\section{Introduction:}

Pranayam is derived from two Sanskrit words, prana, which means vital force of life energy, ayama means to prolong [1]. Asan, Pranayama and meditation are three main techniques of yoga practice in India over thousands of years to attained functional harmony between the body and mind [4].

Breath is dynamic bridge between the body and mind hence, life experiences can distort breathing pattern. Pranayam is the art of prolongation and control of breath helps in bringing conscious awareness to breathing and reshaping of breathing habits and patterns [2,11]. Meditation is a yogic process of providing deep rest to the system by allowing the mind to calm down to its basal states. It is often looked upon as a relaxation technique to be used for treating stress relate illnesses [6,9]. Different types of pranayama produce different physiological cardiovascular response in normal young individuals. During right nostril pranayam and alternate nostril pranayama, the heart rate increased [8]. Where during left nostril pranayama is a technique of controlling and modulating breath and meditation, a process through which one attains meditation a state of deep rest yet active state of mind [4]. Anulom vilom on a regular basis can relieve the symptoms and reverse conditions like diabetes, heart disease and high cholesterol levels [8]. Diabetes, often referred by doctors as diabetes mellitus, describe a group of metabolic disease in which the person has high blood glucose, either because insulin production is inadequate or because the body's cell do not respond properly to insulin both patient with high blood sugar will typically experience polyuria, they will become increasingly thirsty and hungry [3]. In type 2 diabetes, the pancreas makes some insulin but it is not produced in the amount body needs and it does not work effectively [3].

Mediation help to relax and give the fresh tools for dealing with stress. Life stress is a big issue for all. For those who have Diabetes, stress presents the problems as the direct effect of stress raises the blood glucose levels and under the stress person have the behavior that are not good for health as irregular eating more carbohydrate rich food or laziness.

Type 2 Diabetes result from a combination of genetic and environmental factors, although there is strong genetic predisposition the risk is greatly increased when associated with life style factors such as high blood pressure, obesity, insufficient physical activity, poor diet and the 'Apple Shape' body where extra weight is carried around waist [3].

\section{Material and Methods:}

Total 30 Patients selected from serial diabetic camps conducted by diabetic association, Amravati branch of India. The 
fasting Blood samples were collected from the people involved in before and after study and equal numbers of healthy controls age matched. Both pre-and post-experiment the blood glucose tested by GOD-POD (Glucose Oxidase Peroxidase) colorimeteric method and confirmed by automatic analyzer in the pathological laboratory[12]. The data was tabulated, statistically analyzed for paired "t" test and graph plotted.accordingly.

\section{Result:-}

The Results are shown in table II and graph plotted. The data collected from T2DM patients were Statistically analyzed by paired ' $t$ ' test, The mean ' $t$ ' test value indicated the significant mean difference (66.963) between pre and post test of diabetic T2DM patients, the calculated ' $\mathrm{t}$ ' value was tested for significant difference at 0.05 level. The patients with regular pranayam and meditation were shown to have decrease blood glucose level table II indicted that calculate ' $\mathrm{t}$ ' ratio 7.6317 is higher than the table value. Hence it is significant and the null hypothesis was rejected. This indicated that there is a significant difference in fasting blood glucose.

Table-1. Name and Duration of Various Pranayama \& Meditation

\begin{tabular}{|c|l|l|}
\hline Sr. No. & \multicolumn{1}{|c|}{ Name } & \multicolumn{1}{c|}{ Duration } \\
\hline 1 & Bhastrika & $3-5$ min. per day \\
\hline 2 & Kapal- Bhati & $5-7$ min par day \\
\hline 3 & Anulom- viloma & $5-10$ min par day \\
\hline 4 & Bharmari & 5 time a day \\
\hline 5 & Meditation & $10-20$ min. per day \\
\hline 6 & Udgit.om uccharan & 5 time a day \\
\hline
\end{tabular}

Table-2. Blood Glucose values during the pranayama and meditation

\begin{tabular}{|c|c|c|c|}
\hline $\begin{array}{c}\text { No. of } \\
\begin{array}{c}\text { Persons } \\
\text { involve } \\
\text { in } \\
\text { study }\end{array}\end{array}$ & $\begin{array}{c}\text { Before } \\
\text { study } \\
\text { Blood } \\
\text { Glucose } \\
\text { Values } \\
\mathrm{mg} / \mathrm{dl}\end{array}$ & $\begin{array}{c}\text { After } \\
\text { Pranayama } \\
\text { and } \\
\text { Meditation } \\
\text { Blood Glucose } \\
\text { Value } \mathrm{mg} / \mathrm{dl}\end{array}$ & $\begin{array}{c}\text { Control } \\
\mathrm{mg} / \mathrm{dl}\end{array}$ \\
\hline 1 & 180 & 90 & 100 \\
\hline 2 & 119 & 81 & 96 \\
\hline 3 & 196 & 98 & 78 \\
\hline 4 & 200 & 93 & 89 \\
\hline 5 & 132 & 88 & 90 \\
\hline 6 & 167 & 87 & 78 \\
\hline
\end{tabular}

\begin{tabular}{|c|c|c|c|}
\hline 7 & 157 & 98 & 89 \\
\hline 8 & 158 & 93 & 90 \\
\hline 9 & 103 & 79 & 94 \\
\hline 10 & 171 & 78 & 76 \\
\hline 11 & 162 & 100 & 88 \\
\hline 12 & 107 & 90 & 92 \\
\hline 13 & 187 & 99 & 83 \\
\hline 14 & 155 & 96 & 87 \\
\hline 15 & 177 & 83 & 90 \\
\hline 16 & 292 & 89 & 94 \\
\hline 17 & 198 & 99 & 86 \\
\hline 18 & 179 & 91 & 82 \\
\hline 19 & 184 & 73 & 77 \\
\hline 20 & 178 & 100 & 79 \\
\hline 21 & 189 & 92 & 98 \\
\hline 22 & 188 & 99 & 79 \\
\hline 23 & 95 & 84 & 89 \\
\hline 24 & 172 & 79 & 98 \\
\hline 25 & 98 & 77 & 83 \\
\hline 26 & 190 & 100 & 74 \\
\hline 27 & 187 & 107 & 99 \\
\hline 28 & 100 & 97 & 70 \\
\hline 29 & 102 & 78 & 102 \\
\hline 30 & 93 & 90 & 81 \\
\hline
\end{tabular}

Graph- Blood glucose level of diabetes mellitus patients during the pre and post study of pranayam and meditation..

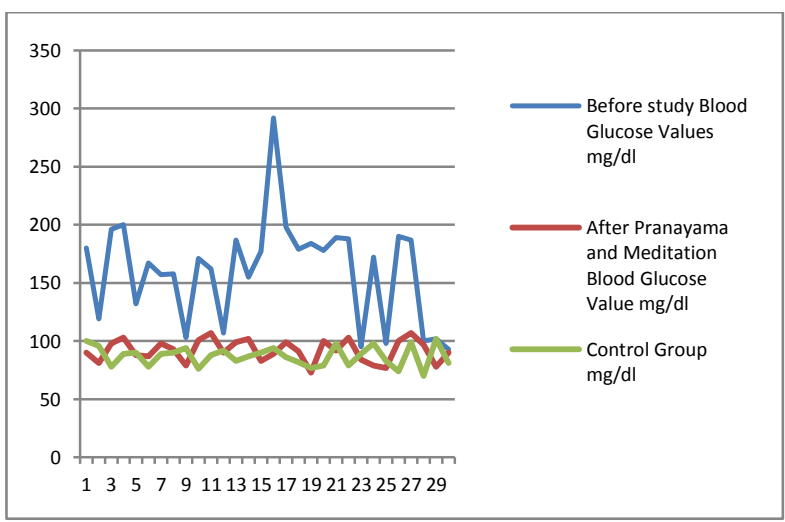

Discussion :-

Over all findings of these studies suggested that pranayam and meditation based practices may have significant beneficial effects on blood glucose and other parameters in T2DM management and prevention. The similar results as in the studies of other investigators and focuses on our similar study. Depression and/or anxiety are risk factors for the development of diabetes [15]and vice versa [16,17]. This may occur due to genetic, epigenetic or environmental conditions. Regular practice of yoga has been shown to be beneficial in reducing depression and anxiety $[18,19]$ and therefore may affect diabetes in an indirect manner.

Yoga has been useful in geriatric type 2 diabetes where vigorous exercise may not be 
acceptable[20]. Randomized controlled trial showed that in a 6-month period, practice of comprehensive yogic breathing had beneficial effects on cardiac autonomic functions in patients with diabetes who followed the comprehensive yogic breathing program compared to those who were on standard therapy alone [21]. Since cardiac dysfunction has been implicated in sudden cardiac death in diabetes, this finding may translate to practice of yogic breathing program being useful in delaying sudden cardiac death. Any chronic disease like diabetes leads to a decrease in quality of life. Poor quality of life may affect compliance with treatment. A randomized controlled trial has shown that practice of comprehensive yogic breathing program significantly improves physical, psychological, and social domains, and total quality of life [22]. Other studies have also shown increased feeling of well-being with practice of yoga.[14,23].

Pranayam modified various inflatory and deflatory lung reflexes and interact with central neural element to bring new homeostasis in the body[10]. Long term yogic meditation practice experienced better quality of life and functional health life than the general population[7]. Bhastrika is a type of pranayam, breath training shows an increased in parasympathetic activity, that is reduced basal heart rate increase in valsalva ratio and deep breathing differences in heart rate and reduction in fall of systolic blood pressure on posture variation[13]. The anatomical correlates of long term meditation, research found significantly large gray matter volumes in mediators in the right orbito frontal cortex, right thalamus and left inferior temporal gyrus [6]. A few minutes of regular meditation practice acts as an excellent stress buster for the mind and body while stress is the major cause of diabetes, the condition in turn result in patients getting highly stressed about it, which farther aggravates the problem [5].

Conclusion:

Yogic practice such as pranayam, meditation was associated with significant reduction in blood glucose and brings good control in Type 2 Diabetes Mellitus.

\section{References:}

Ankad Roop B, Anita Herur, Shaialja Patil, G.V. Shashikal, Surekha Rani Chinagudi (2011): Effect of Short term Pranayama and Meditation Cardiovascular function in Healthy Individuals. Heart views. Vol.12c2, Pp 58-62.

Bijlani R L (2004): Understanding medical physiology, 3rd Jaypee Brothers,Pp 871910.

Diabetes CO.UK (2014): Diabetic Digital Medi Ltd. the global diabetes community.

Gupta Preeti, Sanjiv Gupta (2016): Evaluation on effect of pranayama and meditation on pulmonary functions in Healthy young Adults. Global Journal For Research Analysis Vol. 5C2, Pp B160.

Health site (2015): Chakra Healing System, Try these 10 yoga poses to keep diabetes under control.

Luder E, Toga A.W, Lepore N, Gaser C (2009): The underlying anatomical correlates of long- term meditation Largehippo campal and frontal volumes of gray matter, Vol.45(3),Pp672-8.

Nagarathna R, Megendra H (2006): Yoga for promotion of positive health Vol.4, Swami Vivekananda Yoga Prakashan.

Shannahoff, Khalsa DS, Kennedy B (1993): The effects of unilateral forced nostril breathing on the heart. Int. J. Neurosci, Vol.60,Pp 47-60.

Shivesh Prakash, Sushant Meshram, Ujwal Ramtekkar (2007): Athletes Yoga is and individuals with sedentary life style. Vol.5 1 (1).Pp 76-80.

Tandop O P (2012): Yoga and it's applications, Best and Taylor's Physiological Basis of medical practice $13^{\text {th }}$ Ed.Pp1217-30.

Telles $\mathbf{S}$, Nagarthna $\mathbf{R}$, Nagendra $\mathbf{H} \mathbf{R}$ (1994): Breathing through a particular nostril can alter metabolism and aultonomic activites. Indian J. Pharmacol, Pp 133-7.

Trinder $\mathbf{P}$ (1969):-Estimation of Glucose Ann.Clin,Biochem.6 ,Pp24.

Varun $M$, Tandon $O P$, Rajkumar $P$, Tarun K S, Stany W L, Nagamma T (2009): Suryana di anulomaviloma Pranayam modifies autonomic activity of heart. $\mathbf{J}$ yoga spring. $8-1$.

Ramachandran A, Snehalatha C, Mary S, Mukesh B, Bhaskar A.D., Vijay V.(. 2006):Indian Diabetes Prevention Programme (IDPP). The Indian Diabetes Prevention Programme shows that lifestyle modification and metformin prevent type 2 diabetes in Asian Indian subjects with impaired glucose tolerance (IDPP-1). Diabetologia;49:289-97. 
Bystritsky A, Danial J, Kronemyer $\mathbf{D}$ (2014): Interactions between diabetes and anxiety and depression: Implications for treatment. Endocrinol Metab Clin North Am ,43:269-83.

Guedes EP, Madeira E, Mafort TT, Madeira M, Moreira RO, Mendonça LM (2013):Body composition and depressive / anxiety symptoms in overweight and obese individuals with metabolic syndrome. Diabetol Metab Syndr;5:82.

Ali N, Jyotsna VP, Kumar N, Mani $\mathbf{K}(2013)$ : Prevalence of depression among type 2 diabetes compared to healthy non diabetic controls. J Assoc Physicians India; $61: 619-21$.

Khalsa MK, Greiner-Ferris JM, Hofmann SG, Khalsa SB(2014): Yoga-Enhanced Cognitive Behavioural Therapy (Y-CBT) for Anxiety Management: A Pilot Study. Clin Psychol Psychother. Gangadhar BN, Naveen GH, Rao MG, Thirthalli J, Varambally $\quad \mathbf{S}(2013)$ : $\quad$ Positive antidepressant effects of generic yoga in depressive out-patients: A comparative study. Indian J Psychiatry ,55 Suppl 3:S369-73.

Beena RK, Sreekumaran E(2013): Yogic practice and diabetes mellitus in geriatric patients. Int J Yoga :47-54.

Jyotsna VP, Dhawan A, Sreenivas V, Deepak KK, Singla R. Completion report (2014):Effect of Comprehensive Yogic Breathing program on type 2 diabetes: A randomized control trial. Indian $\mathbf{J}$ Endocrinol Metab 18:582-4.

Jyotsna VP, Joshi A, Ambekar S, Kumar N, Dhawan A, Sreenivas V(2012): Comprehensive yogic breathing program improves quality of life in patients with diabetes. Indian $\mathbf{J}$ Endocrinol Metab;16:423-8.

Sharma R, Gupta N, Bijlani RL(2008): Effect of yoga based lifestyle intervention on subjective well-being. Indian J Physiol Pharmacol ,52:123-31. 